\title{
Матеріали підготували:
}

Яременко О.О. канд. єконом. наук Балакірєва О.М., канд. соціол. наук

Дмитрук Д. А., стариий науковий співробітник

У цьому номері жсурналу наводимо результати соціологічного опитування населення Украӥни, проведеного Украӥнським інститутом соціальних досліджень та Центром політичного менеджсменту. Опитування проводилося з 9 по 15 червня 2004 року в усіх областях Украӥни, АР Крим та місті Києві. Усього опитано 2100 респондентів віком від 18 років і старше. Стандартні відхилення при достовірних 95 відсотках і співвідношенні змінних вів 0,1:0,9 до 0,5:0,5 становлять 1,31-2,18 відсотка.

\section{СОЦІАЛЬНО-ПОЛІТИЧНІ ОРІЕНТАЦЇ̈ ГРОМАДЯН УКРАЇНИ}

На момент проведення опитування доволі помітна частина громадян продовжувала дистанціюватися від будь-яких політичних течій, оскільки не могла або не бажала ідентифікувати себе з ними. Зокрема, сумарний відсоток тих, хто не підтримував жодного із запропонованих політичних напрямів або не зміг дати певну відповідь, становив понад третину учасників опитування.

Що ж до респондентів, які визначилися зі своїми політичними вподобаннями, то тут найбільший рівень підтримки має національно-демократична та комуністична течії. Як засвідчують отримані результати, рівень підтримки громадянами поєднання ідеї ринкової економіки з ідеями українсько-російського союзу фактично дозволяє вказувати на цей економіко-політичний напрям як на один з провідних. Рівень підтримки екологічної ідеології майже дорівнює рівню підтримки соціал-демократичного напряму.

Загальну картину з політичними вподобаннями ілюструє таблиця 1. Дані наведені у динаміці.

Таблиця 1

Динаміка відповідей респондентів на запитання: “Який ідейно-політичний напрям найбільше відповідас Вашим власним переконанням?”, 2002-2004 pp., \%

\begin{tabular}{|c|c|c|c|c|c|c|c|c|c|c|c|c|c|c|}
\hline & \multicolumn{2}{|c|}{2002} & \multicolumn{7}{|c|}{2003} & \multicolumn{5}{|c|}{2004} \\
\hline & 09. & 12. & 02. & 04. & 06. & 09. & 10. & 11. & 12. & 02. & 03. & 04. & 05. & 06. \\
\hline Комуністичний & 13 & 14 & 13 & 13 & 12 & 16 & 14 & 14 & 14 & 11 & 11 & 13 & 14 & 15 \\
\hline Національно-демократичний & 14 & 13 & 13,5 & 12,5 & 12 & 11 & 11 & 10 & 10 & 14 & 14 & 13 & 11 & 13 \\
\hline $\begin{array}{l}\text { Політичний напрям, що } \\
\text { поєднує ідеї ринкової } \\
\text { економіки з ідеями } \\
\text { возз`єднання України з Росією }\end{array}$ & 9 & 11 & 8 & 8 & 5 & 8 & 6 & 7 & 7 & 8 & 9 & 10 & 8 & 9 \\
\hline Екологічний («зелені») & 4 & 6 & 8 & 8 & 9 & 9 & 7 & 8 & 6 & 7 & 6 & 9 & 8 & 7 \\
\hline Соціал-демократичний & 13 & 11 & 10 & 8 & 7 & 10 & 9 & 8 & 10 & 7 & 7 & 9 & 8 & 6 \\
\hline Національно-радикальний & 1 & 1 & 1 & 1 & 2 & 1 & 1 & 1 & 1 & 1 & 2 & 1 & 1 & 1 \\
\hline Соціалістичний & 3 & 3 & 5 & 4 & 2 & 4 & 4 & 4 & 3 & 4 & 5 & 5 & 5 & 4 \\
\hline Християнсько-демократичний & 2 & 3 & 3 & 3,1 & 2 & 3 & 3 & 3 & 3 & 4 & 3 & 3 & 4 & 2 \\
\hline Ліберальний & 2 & 2 & 1 & 2 & 1 & 1 & 1 & 2 & 1 & 1 & 1 & 1 & 2 & 1 \\
\hline Анархістський & 0,4 & 0,6 & - & 0,2 & - & - & - & - & - & - & - & - & - & - \\
\hline Інший & 0,4 & 0,3 & 0,5 & 0,2 & 1 & 0 & 1 & 1 & 0 & 1 & 2 & 1 & 0,2 & 1 \\
\hline Жодний & 12 & 16 & 14 & 18 & 17 & 17 & 20 & 18 & 20 & 18 & 17 & 16 & 15 & 17 \\
\hline $\begin{array}{l}\text { Я не орієнтуюся в політичних } \\
\text { течіях }\end{array}$ & 17 & 14,1 & 15 & 16 & 21 & 15 & 17 & 17 & 17 & 17 & 18 & 13 & 17 & 18 \\
\hline Важко відповісти & 9,2 & 5 & 8 & 6 & 9 & 5 & 6 & 7 & 8 & 7 & 5 & 6 & 6,8 & 6 \\
\hline
\end{tabular}


Логічним продовженням вивчення політичних орієнтацій громадян України стало запитання щодо підтримки певних політичних партій, які б респонденти підтримували своїм членством, участю в акціях або були їх симпатиками.

На момент проведення опитування серед різних політичних блоків/партій рівень підтримки блоку В. Ющенка виглядав найбільш переконливим. На другому місці, відповідно до електоральних уподобань громадян України, знаходиться Комуністична партія України. Третє місце посідає Партія регіонів України.

До переліку партій, які б змогли перетнути новий 3\% бар'єр також у травні цього року ми можемо віднести Соціал-демократичну партію України (об'єднану), Соціалістичну партію України, Блок Юлії Тимошенко.

Таблиця 2

Розподіл відповідей респондентів на запитання:

“Якби парламентські вибори відбулися наступної неділі і в бюлетень для голосування були включені такі партії та блоки, то за кого 3 них

Ви проголосували б?”, \%*

\begin{tabular}{|l|c|c|c|}
\hline & $\begin{array}{c}\text { Квітень } \\
\mathbf{2 0 0 4}\end{array}$ & $\begin{array}{c}\text { Tравень } \\
\mathbf{2 0 0 4}\end{array}$ & $\begin{array}{c}\text { Червень } \\
\mathbf{2 0 0 4}\end{array}$ \\
\hline Блок Віктора Ющенка "Наша Україна" & $\mathbf{1 8}$ & $\mathbf{2 0}$ & $\mathbf{1 8}$ \\
\hline Комуністична партія України & $\mathbf{1 1}$ & $\mathbf{1 2}$ & $\mathbf{1 3}$ \\
\hline Партія регіонів України & $\mathbf{7}$ & $\mathbf{7}$ & $\mathbf{8}$ \\
\hline Соціалістична партія України & $\mathbf{5}$ & $\mathbf{4}$ & $\mathbf{3}$ \\
\hline Соціал-демократична партія України (об'сднана) & $\mathbf{4}$ & $\mathbf{4}$ & $\mathbf{3}$ \\
\hline Блок Юлії Тимошенко & $\mathbf{3}$ & $\mathbf{3}$ & $\mathbf{3}$ \\
\hline \hline Партія Зелених України & 3 & 2 & 2 \\
\hline Виборчий блок "ЗУБР" (За Україну, Білорусію, Росію) & 2 & 1 & 1 \\
\hline "Жінки за майбутнє" всеукраїнське політичне об'єднання & 2 & 1 & 1 \\
\hline Аграрна партія України & $<1$ & 1 & 1 \\
\hline Блок політичних партій "Руський блок" & 1 & 1 & $<1$ \\
\hline Виборчий блок " Команда Озимого Покоління" & 1 & 1 & $<1$ \\
\hline Виборчий блок Народний Рух України за єдність & $<1$ & 1 & $<1$ \\
\hline Всеукраїнська партія "Нова сила" & $<1$ & 1 & $<1$ \\
\hline Демократична партія України & $<1$ & 1 & 1 \\
\hline Народно-демократична партія & 1 & 1 & 1 \\
\hline Партія "Жінки України" & 1 & 1 & $<1$ \\
\hline Партія промисловців і підприємців України & 1 & 1 & $<1$ \\
\hline Політична партія "Трудова Україна" & 1 & 1 & $<1$ \\
\hline Прогресивна соціалістична партія України & 1 & 1 & $<1$ \\
\hline Інші партії (разом) & $5 * *$ & 1,6 & $6 *$ \\
\hline Не підтримую жодної з названих політичних партій & 19 & 22 & 23 \\
\hline Важко відповісти & 14 & 11,4 & 16 \\
\hline
\end{tabular}

* Політичні партії та блоки, які отримали менще 1\% голосів респондентів, до таблиці не включені.

** Включаючи партії, які отримали менше 1\% голосів вибориів, але були включені в розподіл відповідей. 